\title{
Influence of Service Quality on Customer Patronage Intention in commercial banks: an Empirical Evidence
}

\author{
Uvais.M ${ }^{1}$ E.Sulaiman ${ }^{2}$ \\ ${ }^{1}$ Research Scholar, School of Management and Business Studies, Mahatma Gandhi University, Kottayam, \\ ${ }^{2}$ Associate Professor, School of Management and Business Studies, Mahatma Gandhi University, Kottayam,
}

\begin{abstract}
Recently the commercial banking industry started to face a set of radically new challenges that has increased an overall risk to retain the customers in the industry. The scenario also changed from the past. Like any other industry, especially retail, banks also have to spare no efforts to retain these customers as there are a lot many options in this competitive market. In such a context, our paper tries to develop a model for the customer patronage intention in commercial banks with respect to the service quality aspects provided by the banks and the perception of the customer too. 180 samples across the Kerala state have been taken for the study. Statistical tools like Exploratory Factor Analysis, Correlation, Descriptive Statistics, KMO, Reliability and Validity test also applied to complete the study.
\end{abstract}

Keywords: Service Quality, Patronage Intention, Commercial Banks

\section{Introduction}

Banking industry is the very important financial institution of a county only because it support and maintain the economic stability of a country and it controls Gross Domestic Product (GDP) to an extent. As far as our county is concerned it is trying the level best to compete with foreign financial institution and as a part of it the recent merging of five state banks and associates to the India's biggest banking chains. All institutions especially the financial ones barely depends upon its customers and their cooperation ahead for the successful running. The services provided by such institutions play vital roles and it highly impacts on their patronage intention towards the particular industry. In the business play, customers are tend to show their patronage towards the more profitable banks and due to that the many other banks suffered losses due to less concertation to this part. One of the most important parts of this industry is the service they provide and the perceived quality of that service by the customers which are evaluated by them during the service encounter.(Parasuraman et.al., 1985). Once the perceived quality by the customers get its satisfied level, they become loyal to the banks and its impacts on the attitude and behavior of the customers which results in actual patronage intention. (Chaudhari\&Holbrook, 2001). In such a scenario a study to understand the relationship between service quality and patronage intention gets it relevance at it most preference and the attempt to develop a model also have the recent significance. The researcher had spared no effort to conceptualize this important aspect of the service industry especially the banking in this most competitive era.

\section{Banking industry; an over view}

The global banking scenario is currently undergoing radical transformation owing to liberalization privatization and globalization with measures introduced and controlled by economies of the world. Indian banking industry has nothing different from afore mentioned situation. The banking sector of India can be broadly classified into non-scheduled and scheduled banks. Scheduled banks are further categorized as commercial and cooperative commercial banks consist of nationalized banks, state bank of India and its group banks. Regional rural banks and private banks (foreign and Domestic Old/New) based on ownership. The industry has been growing due to growing competition, changing demographic profile and increased demand for credit form consumers and industry. The banking industry is a highly competitive and worldwide (Hull, 2002). Most bank products are easy to duplicate and when banks provide nearly identical services, they can only distinguish themselves based on price and quality. Therefore, customer satisfaction, loyalty and retention are the only tool to gain strategic advantage and to be top in the competitive environment. It is more economical to keep customers than acquiring new one (Abratt\&Rusell, 1999).

\subsection{Service Quality}

\section{Review of literature}

Zaithaml and Bitner (2003) defined perceived service quality as overall judgment or decision to the superiority of a service. In today's scenario, service quality has got much variety of acceptances as well as it has come forward with different models to measure the particular phenomenon. One of the widely used model to measure the service quality is the model developed by Parasuraman.et.al.,(1988) the model consist of five 
different dimensions of services namely, Tangibility, Reliability, Responsiveness, Assurance and Empathy. The model runs by finding the gap scores between expectation and perception of the customers to a given service encounter. The model got some deficiencies in many contexts as the expectation-perception get confused and later Cronin and Tylor (1992) had an extension of this measurement called SERVPERF which dealt with only perception part of the customers and the dimensions remained as the SERVQUAL. In this study the researcher also used the tool of latter and found significant in all aspects.

\subsection{Patronage Intention}

East and Robert (1997) suggests that the patronage intention van be identified form the switching behavior of the customers and the satisfied customers always remain patronized to the company they deals with. Sivadaset.al., (2000) concludes that customer satisfaction itself can be identified as the most important sign of patronage intention. Bolton and Drew (1991) finds that the behavioral intention is the key to patronize and it can be developed by increasing more satisfied customers by adding value to the services delivered. Dahlia and Hanwin (2014) claims that attitudinal loyalty is the very important factor to make customer patronized and that dimension must have given much importance from others. The all literatures focus on behavior as well as other factors which develop patronage to the minds of the customers.

\section{Objectives of the study}

The objectives are formulated as, to extract the factors influencing the service quality and the patronage intention of the customers in commercial banks. To examine the relationship between service quality and patronage intentions

\section{Research design and instrument}

The research is descriptive in nature and the researchers have taken public sector commercial bank customers as sample. In the earlier stage a pilot study was conducted taking 60 samples from the above mentioned group and it was found reliable to continue the actual study. 180 samples were selected for the final study representing three major public sector commercial banks namely State bank of India, Canara bank and Union bank. The primary data was collected using a well-structured questionnaire and the secondary data was obtained from journals, books and other related articles. According to the reviewed literatures, a research model was developed (Figure: 1)

Figure 1: Developed Research Model

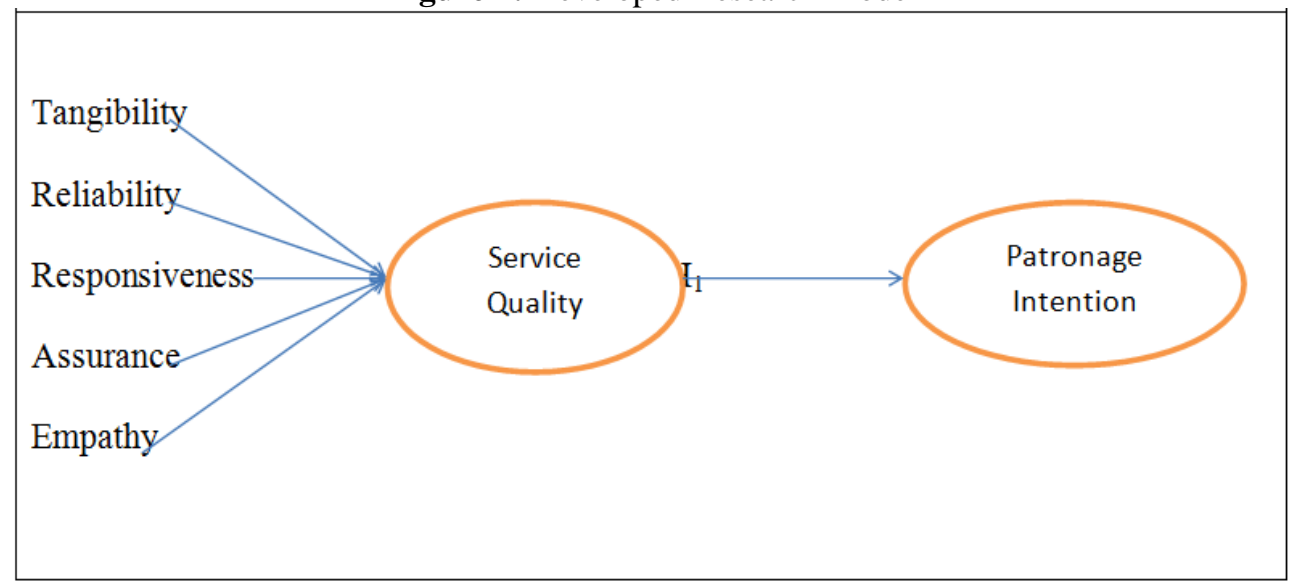

\section{Hypothesis formulation}

There searcher has formulated a hypothesis stating that the perceived service quality has a direct effect on patronage intention. The hypothesis have been tested to find the relationship between overall service quality and patronage intention.

$H_{0}$ : there is no significant relationship between service quality and patronage intention

$H_{l}$ : there is significant relationship between service quality and patronage intention

\section{Reliability and validity}

The scale showed good reliability as the Cronbach's Alpha was shown as 0.861 for service quality and 0.881 for the patronage intention. The content validity was done by asking experts and all responded positively. Finally, the study was carried out bearing in the mind all these critical factors and its adequacy. (Table 1) 
Table 1: Reliability Statistics

\begin{tabular}{|c|c|c|}
\hline Variables & Cronbach's Alpha & No. of Items \\
\hline Service quality & .861 & 22 \\
\hline Patronage Intention & .881 & 18 \\
\hline
\end{tabular}

\# Source: Data Analysis

\section{KMO and Bartlett's Test}

The KMO and Bartlett's Test was conducted to find out the adequacy of the sample in the given study. It was found that the KMO coefficient $(0.818)$ is more than 0.05 and it was concluded that the sample is adequate to continue the study further. (Table 2)

Table 2: KMO and Bartlett's Test

\begin{tabular}{|l|l|r|}
\hline \multicolumn{3}{|c|}{ KMO and Bartlett's Test } \\
\hline \multicolumn{2}{|c|}{ Kaiser-Meyer-Olkin Measure of Sampling Adequacy } & 0.818 \\
\hline \multirow{2}{*}{ Bartlett's Test of Sphericity } & Approx. Chi-Square & 3860.253 \\
\cline { 2 - 3 } & df & 231 \\
\cline { 2 - 3 } & Sig. & .000 \\
\hline
\end{tabular}

\#source: data analysis

\subsection{Descriptive statistics}

\section{Analysis and Interpretation}

Among the respondents, $58 \%$ of the replies from the northern part of the Kerala showed their satisfaction and only $6 \%$ indicated as they are highly satisfied. In the case of Central part, $69 \%$ marked as satisfied and $9 \%$ as highly satisfied. Coming to southern part, only $40 \%$ of the respondents were having satisfaction and the highly satisfied pool was remained at $6 \%$. Among the total samples 110 were male and 70 were the female respondents. Among them $60 \%$ of the male were showed their satisfaction towards the bank services and $53 \%$ of the female also stood up with the bank services and, among the married respondents $55 \%$ of them are satisfied and $52 \%$ of the unmarried respondents replied as satisfied. In the sense of education, secondary level respondents are showing more happiness (70\%) followed by graduate $(60 \%)$ and post graduate $(53 \%)$. When the researcher made an attempt to check the satisfaction levels in the basis of occupation, it was found that, retired people are showing more happiness (65\%) followed by self-employed respondents $(60 \%)$ and those who having job in private sector also(50\%). The least satisfied team on the basis of occupation was business people $(44 \%)$ followed by public sector workers $(51 \%)$. The interesting figures on the basis of the income level were the low income people are having more satisfaction towards the bank services. In the particular study, $69 \%$ of the respondents from the low income were satisfied and from the high income, only $38 \%$ are satisfied with it. The middle income people respectively showed their satisfaction as $53 \%$ and $54 \%$

\subsection{Exploratory Factor Analysis}

Table 3 clearly mentions about the validity of each factor after conducting exploratory factor analysis. Service quality's five dimension and patronage intention's three factors were run for EFA and all were loaded at subsequent values and the factors clearly explain the variances. From the factors of service quality, tangibility factors explain 68.32 variance followed by empathy (62.42\%), reliability $(59.52 \%)$, responsiveness $(53.42 \%)$ and assurance (49.31\%). it's obvious that tangibility factor is the most important to service quality which plays vital role in bringing the customer perception at the peak level. In the patronage intention dimensions, all factors were loaded conveniently and the recommendation factor was shown the most important factor which explains maximum variance $(62.65 \%)$ to the patronage intention. Word of mouth factor shoed $59.32 \%$ followed by personal experiences (58.54)

Table 3: Exploratory factor analysis

\begin{tabular}{|c|c|c|c|c|c|c|c|}
\hline \multicolumn{4}{|c|}{ SERVICE QUALITY } & \multicolumn{4}{|c|}{ PATRONAGE INTENTION } \\
\hline FACTORS & $\begin{array}{l}\text { FACTOR } \\
\text { LOADINGS }\end{array}$ & $\begin{array}{l}\text { Variance } \\
\text { Explained } \%\end{array}$ & $\begin{array}{l}\text { Cronbach's } \\
\text { Alpha }\end{array}$ & FACTORS & $\begin{array}{l}\text { FACTOR } \\
\text { LOADING }\end{array}$ & $\begin{array}{l}\text { Variance } \\
\text { Explained } \%\end{array}$ & $\begin{array}{l}\text { Cronbach's } \\
\text { Alpha }\end{array}$ \\
\hline Tangibility & & $68.32 \%$ & 0.821 & $\begin{array}{l}\text { Personal } \\
\text { Experience }\end{array}$ & & $58.54 \%$ & 0.834 \\
\hline T1 & .816 & & & P1 & .618 & & \\
\hline $\mathrm{T} 2$ & .822 & & & P2 & .658 & & \\
\hline T3 & .537 & & & P3 & .747 & & \\
\hline $\mathrm{T} 4$ & .633 & & & P4 & .802 & & \\
\hline Reliability & & $59.52 \%$ & 0.881 & P5 & .748 & & \\
\hline R1 & .539 & & & Recommendations & & $62.65 \%$ & 0.912 \\
\hline R2 & .763 & & & P6 & .721 & & \\
\hline
\end{tabular}


Influence of Service Quality on Customer Patronage Intention in commercial banks: An Empirical

\begin{tabular}{|c|c|c|c|c|c|c|c|}
\hline R3 & .776 & & & P7 & .731 & & \\
\hline $\mathrm{R} 4$ & .819 & & & P8 & .701 & & \\
\hline R5 & .759 & & & P9 & .527 & & \\
\hline Responsiveness & & $53.42 \%$ & 0.791 & $\mathrm{P} 10$ & .772 & & \\
\hline Res1 & .661 & & & $\mathrm{P} 11$ & .628 & & \\
\hline Res2 & .563 & & & $\mathrm{P} 12$ & .576 & & \\
\hline Res3 & .782 & & & P13 & .488 & & \\
\hline Res4 & .616 & & & Word of Mouth & & $59.32 \%$ & 0.852 \\
\hline Assurance & & $49.31 \%$ & 0.891 & P14 & .634 & & \\
\hline A1 & .545 & & & P15 & .527 & & \\
\hline $\mathrm{A} 2$ & .797 & & & P16 & .711 & & \\
\hline A3 & .587 & & & P17 & .770 & & \\
\hline A4 & 591 & & & P18 & .569 & & \\
\hline Empathy & & $62.42 \%$ & 0.862 & & & & \\
\hline E1 & .595 & & & & & & \\
\hline E2 & .551 & & & & & & \\
\hline E3 & .731 & & & & & & \\
\hline E4 & .832 & & & & & & \\
\hline E5 & .836 & & & & & & \\
\hline
\end{tabular}

\#source: data analysis

\subsection{Correlations Analysis (Pearson Correlation)}

To find the relationship between service quality and patronage intention, the following null and alternative hypothesis have been tested for "service quality of commercial banks have a positive effect on customer patronage intention".

$H_{0}$ : there is no significant relationship between service quality and patronage intention

$H_{l}$ : there is significant relationship between service quality and patronage intention

Table 4: Correlation

\begin{tabular}{|l|r|r|r|r|r|}
\hline Variable & \multicolumn{1}{|l|}{ Correlation } & Lower bound & Upper bound & Z & P-value \\
\hline $\begin{array}{l}\text { Service quality- } \\
\text { Patronage intention }\end{array}$ & 0.721 & 0.612 & 0.641 & 15.812 & $<0.001$ \\
\hline
\end{tabular}

\#source: data analysis

The hypothesis were framed to check whether service quality has any significant relation with patronage intention and the same was tested using $Z$ test. Since the calculated $p$-value $(0.001)$ is less than the level of significance (0.05), the null hypothesis is rejected (table 4 ) and it is found that there is a significant relationship between service quality and patronage intention. The correlation coefficient gives the value to determine the strength of the relationship, were +1 indicates positive linear relationship and -1 denotes absolute inverse relationship. 0 values show no relationship.

\section{$X$. Findings and managerial implications}

In a competitive world and a fast changing economic scenario, each and every commercial bank have to spare no effort to understand what the customer want and what they perceive as the best quality of services. It is also mandatory that, the customer's attitude towards each service have to be carefully noted and the way they patronize the bank must to be taken seriously. The present study put forward many interesting things. First and most important is that, form the five dimensions of service quality, tangibility have more influence towards the service encounters. It means that, the infrastructure, location, the facility inside the banks are mostly seen and recognized by the customers and that parts have to be maintained well by the authority. The next dimension which showed maximum variance to service quality was empathy which means that, the employees attitude towards the customers are always taken into serious account by the customers. It also means that, the empathy dimension is the very critical to a financial institution and it also be developed only through better human resource and their full cooperation and intimacy. The next factor which makes more contribution to service quality is reliability that also very edging factor to the financial institutions is concerned. Unless people find it reliable, they won't be ready to do the business with such industries especially in the matter of money and money related issues. The penultimate dimension which adds more to service quality was responsiveness followed by assurance. The first one denotes to the patience part of customers who always pay full attention to get their service to be fulfilled at good manner. The assurance factor also plays critical role, but people will start doing transaction only after they felt assured. So that, that factor may not get enough wait during service encounter as they scored much before starting the deal. The dependent variable patronage intention also reveals some unique findings that, the recommendation factor is more influencing to the variable followed by word of mouth and personal experiences. It is found that at all dimensions, there is a significant positive relationship between service quality and patronage intention in the commercial banks in Kerala. 


\section{Limitations, Conclusion and Scope for further research}

The study is conducted with a sample size of 180 and it would found some difficulties while generalizing the result to the actual scenario but it can be adapted to an extent. Coming to the conclusion, it is found that there is a significant relationship between service quality and patronage intention and all the dimensions of both independent and dependent variables loaded significantly. There is a scope for further research to find out the role of demographic variables in moderating and mediating patronage intention and then the influence of service quality on the later.

\section{References}

[1] Parasuraman.A. Zeithaml. V.A., and Berry.L.L (1985) A conceptual model of service quality and its implication for future research. Journal of Marketing.49(4).41-50

[2] Chaudahri.A and Holbrook. M.B (2001).The chain of effect from brand trust and brand effect to brand performance: the role of brand loyalty. Journal of Marketing.65.81-93

[3] Zeithaml.V.A. and Bitner.M.J (2003) Service Marketing: integrating customer focus across the firm.McGraw-Hill, New York

[4] Parasuraman.A.,Zeithaml. V.A., and Berry.L.L (1988) SERVQUAL: a multiple item scale for measuring customer perception of service quality. Journal of Retailing.64(1).12-40

[5] Cronin, J.J. and Taylor, S.A (1992) Measuring service quality: a reexamination and extension. Journal of Marketing, 56,55-68

[6] East, Robert.(1997) Consumer Behavior: Advances and Apppications. Marketing: London Prentice Hall.

[7] Sivadas, Eugene, Jamie L.Prewitt-Baker (2000) An Examination of the Relationship between Service Quality, Customer Satisfaction and Store Loyalty. International Journal of Retail and Distribution Management, 208(2), 73-82

[8] Bolton, R.N., Drew, J.H., (1991) A Multistage Model of Customer, Assessment of Service Quality and Value. Journal of Consumer Research, 17(4)375-385

[9] Dahlia,D., Hanwin, C(2014) The influence of perceived service quality, attitudinal loyalty and corporate social responsibility on repeat patronage intention in retail banking in Indonesia,Journal of Business and Retail Management Research8(2)16-23 